\title{
Tyrosinase Activity and Melanogenic Effects of Lespedeza bicolor Extract in vitro and in vivo
}

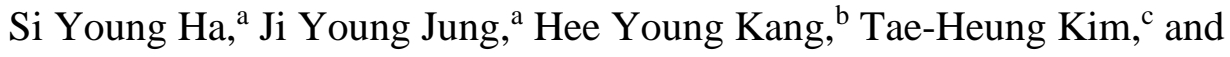 \\ Jae-Kyung Yang ${ }^{a *}$
}

\begin{abstract}
Lespedeza bicolor (L. bicolor) is used for medicinal purposes because of its various biological and pharmacological activities. In this study, the effects of $L$. bicolor ethanol extract on the treatment of vitiligo were investigated. The determination of melanin content in melanocytes was measured using B16 melanoma cells and C57BL/6J Ler-vit/vit mice. Finally, the quercetin content in $L$. bicolor were qualitatively analyzed using HPLC. The results obviously indicated that the $L$. bicolor extract enhanced melanogenesis and increased tyrosinase activity in cultured melanoma cells and C57BL/6J Ler-vit/vit mice. Treatment with L. bicolor extract led to a higher content of melanin and eumelanin in C57BL/6J Ler-vit/vit mice hair than in control (untreated) mice, which demonstrated the therapeutic effect of hair-graying associated with vitiligo. There was a notable increase in melanocytes in the skin of C57BL/6J Ler-vit/vit mice treated with $L$. bicolor extract compared with the control. L. bicolor extract was a potent tyrosinase and melanin synthesis activator in B16 melanoma cells. C57BL/6J Ler-vit/vit mice treated with L. bicolor extract had significantly higher melanin content in hair than the untreated control. The results suggest that $L$. bicolor extract is a potential alternative treatment for improvement of vitiligo.
\end{abstract}

Keywords: Lespedeza bicolor; Melanogenesis; Tyrosinase activity; Vitiligo

Contact information: a: Division of Environmental Forest Science/Institute of Agriculture and Life Science, Gyeongsang National University, Jinju, 52828, Republic of Korea; b: Department of Dermatology, Ajou University School of Medicine, Suwon, 16499, Republic of Korea; c: White-Line Skin Clinic, Changwon, 51496, Republic of Korea; *Corresponding author: jkyang68@ gmail.com

\section{INTRODUCTION}

Vitiligo is usually an acquired pigment disorder, a skin disease caused by the loss of the melanin pigment in the epithelium. Vitiligo occurs in $1 \%$ of the world's population and affects all races. Different studies suggest that some genetic mechanisms are involved in the etiology of vitiligo; in some cases, at least $30 \%$ of people have a family history. The exact cause of this disease is not yet known, and only the period of remission and exacerbation is known. Depigmentation might be an option, but such radical transformations may have a serious impact on a patient's cultural identity.

In vitiliginous areas, melanocytes are present in the skin but are in an inhibited state of functional activity. When melanocyte activity is affected, melanin is not synthesized in the melanosomes of melanocytes. In addition, the development of vitiligo is related to the rates of synthesis and decay of tyrosinase. Many studies have investigated the importance of tyrosinase in the regulation of racial pigmentation. Song et al. (1994) showed that tyrosinase was an enzyme important in melanin formation.

The current treatment options for vitiligo include medication, surgery, and 
adjunctive therapies (those used along with surgical or medical treatments). Whitton et al. (2016) reported that there are several ways to improve the appearance of vitiligo, but the effect is limited. Narrowband ultraviolet B (NB-UVB) phototherapy is problematic because the resulting repigmentation is transient. Skin grafting techniques are the most effective interventions, but they can only be used with stabilized or segmental types of vitiligo, which are less common. In summary, there is currently no satisfactory solution to vitiligo, and the patients are impacted for life.

The study of local knowledge of natural resources has become increasingly important in the investigation of the development of medicines without side effects. Many studies are underway to find potential pigment for the treatment of vitiligo. Piper nigrum L. fruit extract has growth-stimulatory activity in melanocytes. In addition, the extracts from Cucumis melo and Ammi visnaga fruits have been studied. Wood extracts have been tested also as a treatment for vitiligo. In studies by Szczurko et al. (2011), the potency of oral Ginkgo biloba extract to halt progression of active vitiligo was evaluated. The wood extract treatments studied were Angelica sinensis root extract and Ammi majus L. extract. Lin et al. (1999) found that out of 28 herbal extracts screened, significant stimulation $(\mathrm{p}<0.05)$ of melanocyte proliferation was observed using aqueous extracts of herbs. Tahir et al. (2010) reported that Polylpodium leucotomos extract has been used for the treatment of vitiligo for more than 10 years in Europe. Madhogaria and Ahmed (2010) reported a patient who developed depigmented patches after using a cream containing kojic dipalmitate, licorice root extract, and Mitracarpus scaber extract.

As a medicinal plant, Lespedeza bicolor (L. bicolor) is used in folk medicine for white patches on the body, such as leucoderma and vitiligo. Despite its established popular use for the treatment of vitiligo, there are few reports in the literature on this property. Similar previous studies have investigated the effects of flavonoids, contained in many $L$. bicolor extracts, on tyrosinase and the therapeutic effects on inflammation (Samiullah et al. 2012; Rafiq et al. 2013). In addition, quercetin, a component of L. bicolor extract, was reported to induce the upregulation of melanogenesis and enhance tyrosinase activity in dose- and time-dependent manners (Nagata et al. 2004).

Therefore, L. bicolor extract could be used as a potential resource for plant-based pharmaceutical products for melanogenesis. In vitro and in vivo experiments were conducted to determine the effect of $L$. bicolor extract on vitiligo treatment. The cytotoxicity, tyrosinase activity, and melanin content were analyzed in B16 melanoma cells in vitro. The melanin content, eumelanin content, and histologic analysis were examined in C57BL/6J Ler-vit/vit. A mice model for vitiligo, an acquired cutaneous depigmentary disorder, has been established and given the provisional genetic designation C57BL/6J Lervit/vit on Boissy et al. (1987). Through this study, the potential of L. bicolor for the treatment of vitiligo was examined.

\section{EXPERIMENTAL}

\section{Materials}

Preparation of extract

The plant materials were obtained from the Gyeongsang National University Research Forest, Jinju, South Korea and identified by comparison with the voucher specimen (HCCN: 24239 GBH0000003470) deposited at the Herbarium of the Rural Development Administration-Genebank Center, Jeonju, South Korea. The plants were 
identified by Dr. Hak-gon Kim in the GyeongNam Forest Enviromental Research Institute, Jinju, South Korea. The plants were authenticated by Hee-gon Kang in Gyeongsang National University Research Forest, Jinju, South Korea. The fresh stem of L. bicolor (Fig. 1) was cut into small pieces (length $3 \mathrm{~cm}$ ) and dried over-night at room temperature. The dried, L. bicolor stem $(500 \mathrm{~g})$ was soaked in $60 \%$ ethanol $10 \mathrm{~L}$ for 1 week at room temperature. After vacuum filtration (Whatman No. 2 filter paper), the residue was extracted twice more in the same way. The filtrates were evaporated at $45^{\circ} \mathrm{C}$ under reduced pressure using a rotary evaporator to remove the solvent and lyophilized to obtain the crude extract at a yield of $21.8 \%$ (109 g). The extract was stored at $4{ }^{\circ} \mathrm{C}$.

Fig. 1. Lespedeza bicolor

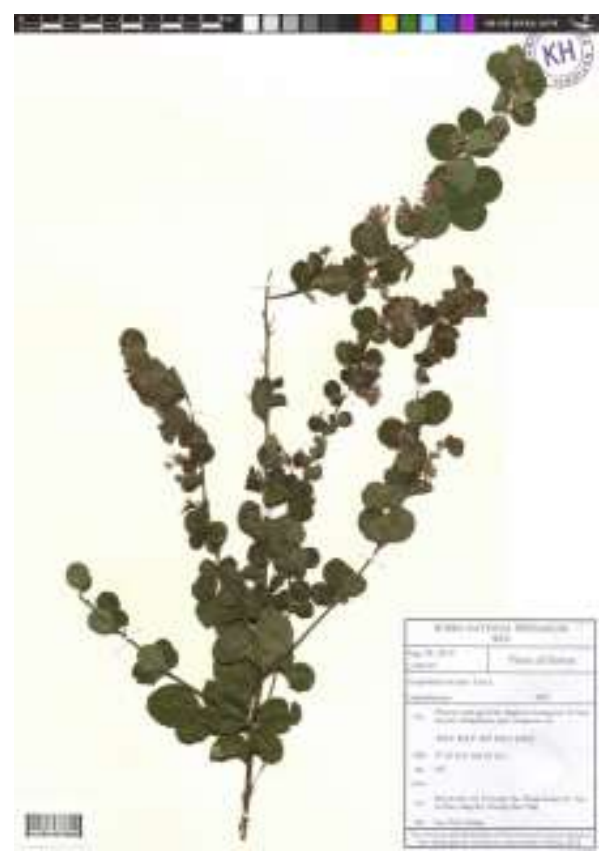

\section{Cell culture}

Mouse melanoma cell lines were provided by Ajou University Medical Center. The B16 melanomas growth medium was composed of Dulbecco's Modified Eagle Medium (DMEM, Invitrogen, Carlsbad, CA), 10\% fetal bovin serum (FBS), and 1\% penicillin/streptomycin (PS). The culture condition was $37^{\circ} \mathrm{C}$ in a humidified atmosphere of $0.5 \% \mathrm{CO}_{2}$.

\section{Cell Cytotoxicity Assay}

Subcultures of B16 cells were seeded in 96 well plates at a density of $7 \times 10^{3}$ B16 cells and cultured for $24 \mathrm{~h}$. The medium was then replaced with $500 \mu \mathrm{L}$ fresh DMEM medium containing $10 \%$ FBS and $1 \%$ PS. Next, $1 \mu \mathrm{L}(5,10,20 \mu \mathrm{g}$ L. bicolor ethanol crude extract/1 mL $60 \%$ ethanol) of the L. bicolor ethanol extract was added to each well and cultured for 3 day. MTT (3-(4,5-dimethylthiazol-2-yl)-2,5-diphenyltetrazolium bromide) was dissolved in phosphate-buffered saline (PBS). After 3 days, $50 \mu \mathrm{L}$ of MTT (at a final concentration of $5 \mathrm{mg} / \mathrm{mL}$ ) were added, and the cells were incubated in $0.5 \% \mathrm{CO}_{2}$ at $37{ }^{\circ} \mathrm{C}$ for $1 \mathrm{~h}$. The plates were shaken with dimethylsulphoxide (DMSO) for $15 \mathrm{~min}$ to dissolve the blue/purple formazan crystals. The percentage of viable cells was quantified by identifying the ability to reduce MTT. The optical density was measured in a ELISA reader 
(Tetertek Multiskan MCC/340, Labsystem, Helsinki, Finland) at $540 \mathrm{~nm}$.

\section{Determination of Melanin Content in Melanocytes}

The assay followed Kubo's method (Kubo et al. 2004) with slight modification. Briefly, subcultures of B16 cells were seeded in $60 \varnothing$ plates at a density of $8 \times 10^{4}$ B16 melanoma cell and cultured for $24 \mathrm{~h}$. The medium was replaced with $3 \mathrm{~mL}$ fresh DMEM medium containing $10 \%$ FBS and $1 \%$ PS. The $1 \mu \mathrm{L}$ of the $L$. bicolor ethanol extract was added to each well and cultured for 3 day. After 3 days, the cells were harvested, suspended in $0.1 \mathrm{~mL} 1 \mathrm{~N} \mathrm{NaOH}-10 \%$ DMSO solution (v/v), and kept at $60{ }^{\circ} \mathrm{C}$ for $6 \mathrm{~h}$ in a water bath. The $90 \mu \mathrm{L}$ test solution was transferred into a 96 well plate and measured in a ELISA reader (Tetertek Multiskan MCC/340, Labsystem, Helsinki, Finland) at $490 \mathrm{~nm}$. The melanin content was determined by calculation from a synthetic melanin standard curve.

\section{Mushroom Tyrosinase Assay}

Measurement of tyrosinase in L-DOPA oxidation of mushroom extracts was carried out as described by Masamoto et al. (2003). The experiment was performed by partially modifying the method. First, $100 \mu \mathrm{L}$ of $0.1 \mathrm{M}$ phosphate buffer was mixed with $20 \mu \mathrm{L}$ of different concentrations from L. bicolor ethanol extract. Then, $20 \mu \mathrm{L}$ of mushroom tyrosinase $(2,000 \mathrm{U} / \mathrm{mL}$ in phosphate buffer) were added to initiate the reaction. The mixture was incubated at $37{ }^{\circ} \mathrm{C}$ for 5 days and then incubated at $37{ }^{\circ} \mathrm{C}$ for 10 min with the addition of 40 microliters of L-DOPA ( $4 \mathrm{mM}$ in $0.1 \mathrm{M}$ phosphate buffer). The mixture was measured in a ELISA reader at $475 \mathrm{~nm}$. The percentage activity of tyrosinase was calculated as follows,

$$
\% \text { activity }=100-(\mathrm{B} / \mathrm{A} \times 100)
$$

where $\mathrm{A}$ is absorbance in $10 \mathrm{~min}$ without sample, and B is absorbance in 10 min with tested sample.

\section{Determination of Cellular Tyrosinase Activity}

Subcultures of B16 cells were seeded in $60 \varnothing$ plates at a density of $8 \times 10^{4}$ B16 melanoma cell and cultured for $24 \mathrm{~h}$. The medium was replaced with $3 \mathrm{~mL}$ fresh DMEM medium containing $10 \% \mathrm{FBS}$ and $1 \% \mathrm{PS}$. The $1 \mu \mathrm{L}$ of the L. bicolor ethanol extract was added to each well and cultured for 3 days. After 3 days, the cells were harvested and lysed by incubation at $-4{ }^{\circ} \mathrm{C}$ for $1 \mathrm{~h}$ in $100 \mu \mathrm{L}$ lysis buffer (PBS pH 6.8, trytone $\times 1001 \%$ ). The lysates were centrifuged at $10,000 \times \mathrm{g}$ for $30 \mathrm{~min}\left(4^{\circ} \mathrm{C}\right)$ to obtain the supernatant as a source of tyrosinase. Tyrosinase activity was assayed as described previously (Nagata et al. 2004). The reaction mixture contained $20 \mu \mathrm{g}$ of lysate, $180 \mu \mathrm{L}$ of $2 \mathrm{mM} \mathrm{L-DOPA} / \mathrm{pH}$ 6.8 PBS, and pH 6.8 PBS. After incubation at $37^{\circ} \mathrm{C}$ for $1 \mathrm{~h}$, Absorbance was measured at a wavelength of $490 \mathrm{~nm}$ to observe the dopachrome formation.

\section{Determination of Melanogenesis in C57BL/6J Ler-vit/vit Mice} Cell culture

All the experimental procedures were performed according to the guidelines of the Committee for Ethical Usage of Experimental Animals at Gyeongsang National University, South Korea: 1.) Act on Experimental Animals Act No. 9932 2010.1.18, 2010.3.19 Other laws amended by the Ministry of Health and Welfare; 2.) Enforcement Decree of the Experimental Animal Act Presidential Decree No. 22075 2010.3.15, 2010.3.19 Other laws amended by the Ministry of Health and Welfare; 3.) Enforcement 
Rules of the Act on Experimental Animals Ministry of Health and Welfare No. 1 2010.3.19, 2010.3.19 Other laws amended by the Ministry of Health and Welfare. The C57BL/6J Ler-vit/vit mice with melanocyte disappearance (Medrano and Nordlund 1990; Slominski and Paus 1993) were used as in vivo animal models. Female C57BL/6J Lervit/vit mice were purchased from SAMTAKO (Gyeonggi-do, South Korea). These mice were stored under the conditions of temperature $\left(20\right.$ to $26^{\circ} \mathrm{C}$ ), humidity (30 to $70 \%$ ), and illumination (lit from 08:00 to 20:00) and used for the experiment. The type of food for mice was standard diets, and crude nutrients were $20 \%$ protein, $4.5 \%$ fat, $6 \%$ fiber, $7 \%$ ash, $0.5 \%$ calcium, and $1 \%$ phosphorus. The bedding material was GLP bedding (SAMTAKO, Gyeonggi-do, South Korea), and number of cage companions was one. The C57BL/6J Lervit/vit mice used in this experiment were 10 to 15 weeks of age. Food and tap water were provided ad libitum. L. bicolor ethanol extract was dissolved in $60 \%$ ethanol and used in the experiment. The mice were randomly divided into two groups of five mice as normal control group with mice treated $60 \%$ ethanol and mice treated $0.2 \mathrm{~mL} / \mathrm{cm}^{2}$ L. bicolor ethanol extract for 5 months without intermission. The control was treated with $60 \%$ ethanol on the opposite side of the same mouse. Repeated experiments were conducted with three sets and changes in hair color was monitored on once a day. When the experiment finished, euthanization was performed by $10 \%$ isoflurane with prolonged exposure at 1,2, and $4 \mathrm{~h}$ after administration, and death was confirmed by exsanguination.

\section{Melanin and eumelanin content measurement in mice hair}

Samples of hair were incubated overnight in $1 \mathrm{M} \mathrm{NaOH}$, as previously described (Green and Wilson 1996). Standards were prepared by dissolving synthetic melanin (Sigma Chemical Co., Poole, Dorset, UK) over the concentration range 0.05 to $0.4 \mathrm{mg} / \mathrm{mL}$ in $1 \mathrm{M}$ $\mathrm{NaOH}$. The absorbance at $500 \mathrm{~nm}$ (total melanin) and $650 \mathrm{~nm}$ (eumelanin) of both standards and sample digests was measured using a Pye Unicam SP8-100 ultravioletvisible spectrophotometer. Because synthetic and endogenous melanin differ in structure, the values presented are comparative rather than absolute.

\section{Histologic examination of C57BL/6J Ler-vit/vit mice}

Throughout this investigation, the standard procedure of Laidlaw and Blackberg (1932) was used, and for carrying out the reaction both freshly prepared sheets of pure epidermis and frozen sections were employed. Where paraffin sections were found to be necessary, as when studying the distribution of melanocytes in hair follicles, specimens comprising the full thickness of the skin were subjected to Dopa treatment after a brief preliminary period of formol fixation. They were then given an additional period in the fixative and sectioned by ordinary methods. The dermo-epidermal was incubated with EDTA solution ( $\mathrm{pH} \mathrm{7.4)}$ ) at $37^{\circ} \mathrm{C}$ for $2 \mathrm{~h}$. Dermo-epidermal was separated with microforcep and washing with saline for $1 \mathrm{~min}$. The dermo-epidermal was incubated with the L-dopa solution at $37^{\circ} \mathrm{C}$ for $1 \mathrm{~h}$. The dopa solution after the reaction was replaced with a new dopa solution, and dermo-epidermal was once more incubated at $37^{\circ} \mathrm{C}$ for $8 \mathrm{~h}$.

Finally, dermo-epidermal was washed with saline for $1 \mathrm{~min}$. Dyed dermoepidermal was fixed with $10 \%$ formalin for $20 \mathrm{~min}$ and washed with distilled water for 3 min. Finally, the dermo-epidermal was dehydrated with $95 \%$ alcohol and $100 \%$ alcohol for $20 \mathrm{~min}$ each and cleared with the xylene for $20 \mathrm{~min}$ (three times). The dermo-epidermal was mounted on slide glass with Canada balsam. 


\section{HPLC Analysis}

Chromatographic analysis was carried out by DAD following RP-HPLC separation installed with HIQ SIL C18V reversed-phase column $(\varnothing 4.6 \mathrm{~mm} \times 250 \mathrm{~mm}$, Young-In Chromass, Anyang-si, South Korea) packed with $5 \mu \mathrm{m}$ diameter particles. The mobile phase was methanol-acetonitrile-water (40:15:45, v/v/v) containing $1.0 \%$ acetic acid. The flow rate and injection volume were $1.0 \mathrm{~mL} / \mathrm{min}$ and $10 \mu \mathrm{L}$, respectively. The standard was quercetin, and both sample and standard were filtered through a $0.45 \mu \mathrm{m}$ membrane filter. HPLC analysis was performed at ambient temperature, and the peak analysis of the chromatography was confirmed by comparison with the retention time of the standard.

\section{Statistical Analysis}

All experiments were run at least in triplicate. SPSS 11.5 (Chicago, IL, USA) and PROC GLM in SAS 9.1 software (Cary, NC, USA) were use for the statistical analysis. A descriptive statistical analysis was made by calculating the mean and standard deviation, and comparison between groups was complemented by a comparison between means (pairwise t-test). $\mathrm{P}<0.05$ and $\mathrm{p}<0.001$ were interpreted as significant.

\section{RESULTS AND DISCUSSION}

\section{Toxicity to B16 Melanoma Cells}

The effects of the extract on cell proliferation were investigated. The cells were exposed to various doses of extract for $72 \mathrm{~h}$, and cytotoxicity was determined by the MTT assay. As shown in Fig. 2, cell viability was maintained for $72 \mathrm{~h}$ after exposure to L. bicolor extract. The cells were treated with various concentrations of $L$. bicolor extract $(5,10$, and $20 \mu \mathrm{g} / \mathrm{mL}$ ), and the cell viability was calculated relative to the control. Cell viability was maintained as L. bicolor extract concentration increased (5, 10, and $20 \mu \mathrm{g} / \mathrm{mL})$. These results indicated that $L$. bicolor extract effectively induced the survival of B16 cells. In addition, L. bicolor extract did not exert cytotoxic effects on B16 melanoma cell proliferation. The percentage viabilities of control cells and those treated with ethanol and various concentration of were not significantly different. Mosmann (1983) reported that the amount of formazan produced in the MTT assay is exactly proportional to the viability of the cells. Therefore, the effects of L. bicolor extract on melanin synthesis and cellular tyrosinase activity were examined subsequently. 


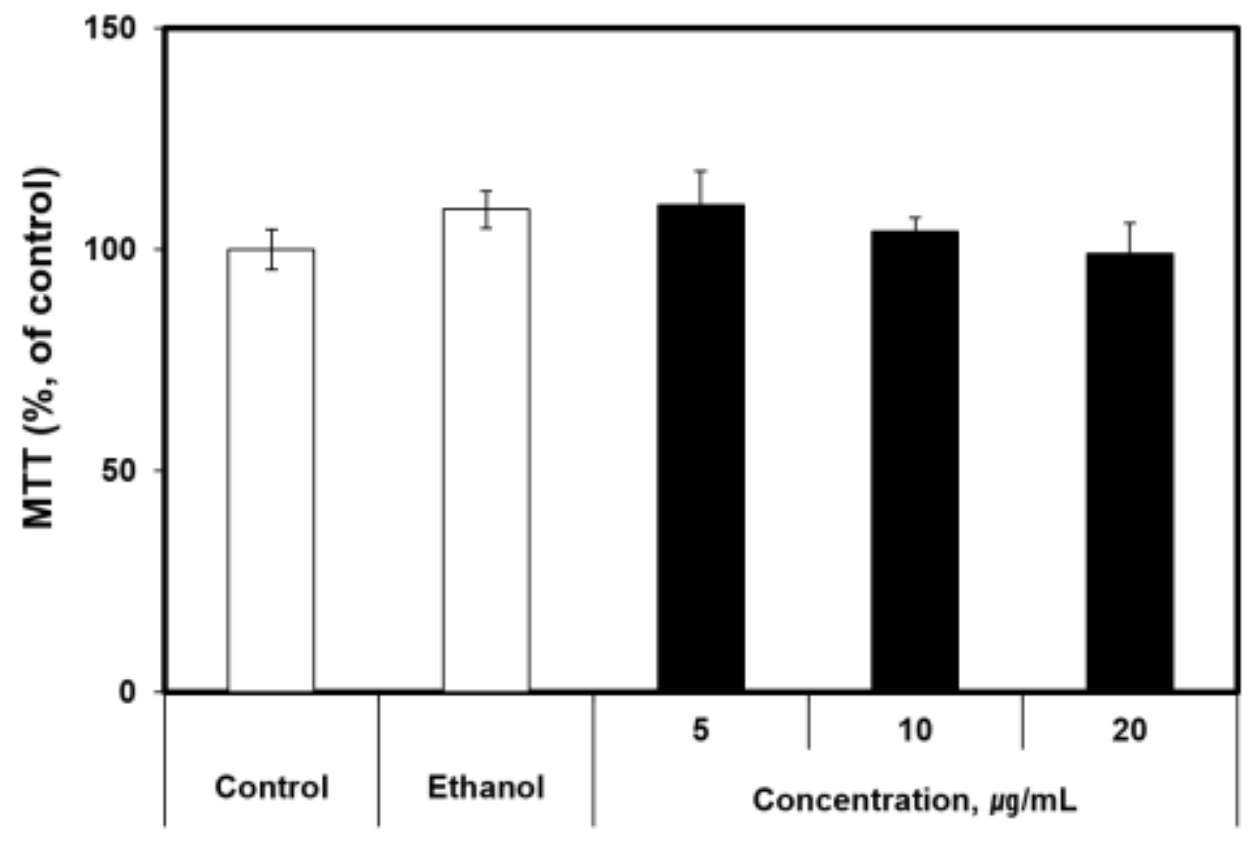

Fig. 2. Effect of $L$. bicolor ethanol extract on cytotoxicity in B16 melanoma cells. Control: untreated; Ethanol: $60 \%$ ethanol; Concentration: L. bicolor ethanol extract

\section{Effect of L. bicolor Extract on Melanin Content in B16 Melanoma Cells}

B16 melanoma cells offer quantifiable markers of cytodifferentiation, such as melanin production, as well as a morphological marker (dendrite formation) (Pomerantz 1964). There is considerable experimental evidence to indicate that growth and melanization are intimately related in melanoma cells (Huberman and Callaham 1979). Lan et al. (2005) reported that melanin content was significantly higher in vitiligo lesions. Itoh and Furuichi (2005) used melanin content as an indicator for the evaluation of antigraying effects in hair and improvements in vitiligo vulgaris. Niu et al. (2016) reported that the main cause of vitiligo was anti-melanogenic activity and that the analysis of melanin content was essential to improve vitiligo. To examine the melanogenic activity of the $L$. bicolor extract, the stimulatory effect of $L$. bicolor extract on melanin was evaluated in B16 melanoma cells. The B16 melanoma cells were treated with the L. bicolor extract at 5,10 , and $20 \mu \mathrm{g} / \mathrm{mL}$ for $72 \mathrm{~h}$. The melanin content was presented as a percentage of the control (vehicle). The following effects of L. bicolor extract on melanogenesis of the B16 melanoma cells were noted. $L$. bicolor ethanol extract exerted a marked stimulatory effect on melanogenesis, without affecting cell proliferation, at concentrations of 5 to $20 \mu \mathrm{g} / \mathrm{mL}$ (Fig. 3). 


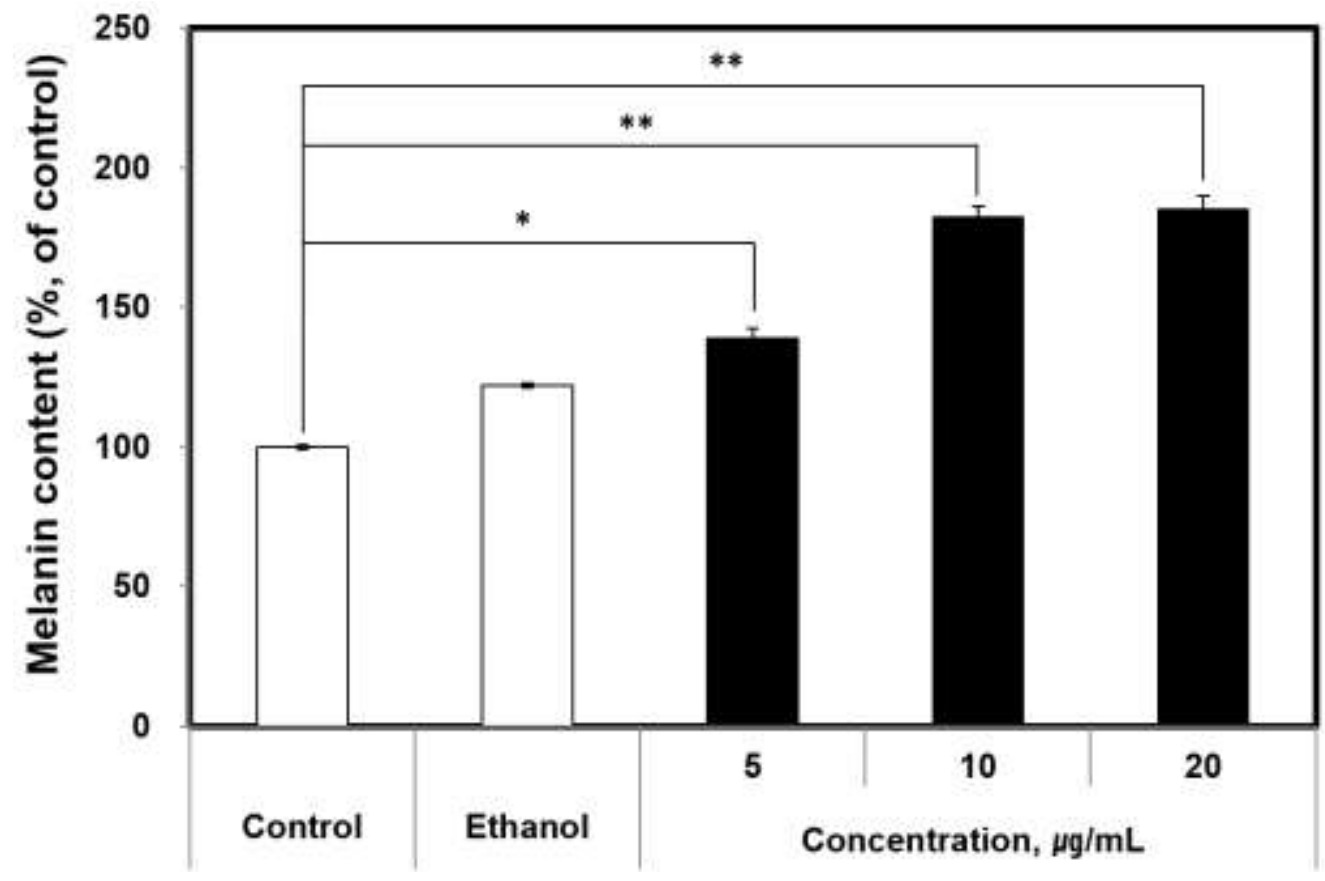

Fig. 3. Effect of L. bicolor ethanol extract on melanin content in B16 melanoma cells. Control: untreated; Ethanol: $60 \%$ ethanol; Concentration: L. bicolor ethanol extract. ${ }^{*} p<0.05$ compared to the untreated control; ${ }^{* *} p<0.01$ compared to the untreated control.

The $L$. bicolor extract exhibited a significant dose-dependent increase on melanin content. The melanin content was $142.11 \% \pm 0.07 \%, 180.00 \% \pm 0.10 \%$, and $181.95 \% \pm$ $0.38 \%$ after treatment with 5,10 , and $20 \mu \mathrm{g} / \mathrm{mL} \mathrm{L.} \mathrm{bicolor} \mathrm{extract,} \mathrm{respectively.} \mathrm{Kang} \mathrm{et}$ al. (2018) reported that the melanin content was $146 \%$ and $110 \%$ after treatment with 8 $\mu \mathrm{g} / \mathrm{mL}$ and $40 \mu \mathrm{g} / \mathrm{mL}$ of Euphorbia supina extract in B16F10 cells, respectively. After the addition of $0.5 \mathrm{mM}$ glycyrrhizin, the cellular melanin content reaches approximately $160 \%$ of control cells (Jung et al. 2001). The Tunisian Capparis spinosa extract stimulates melanogenesis in B16 cells and has been found to increase melanin content by $12 \%$ and $60 \%$ at $0.005 \%$ and $0.05 \%$ extract concentrations, respectively (Matsuyama et al. 2009). The L. bicolor extracts induced similar levels of melanin as previous studies, with a maximum melanin content of $181.95 \%$ after treatment with $20 \mu \mathrm{g} / \mathrm{mL}$ extract. Therefore, the $L$. bicolor extract has the potential as a new natural resource to increase melanin content. 


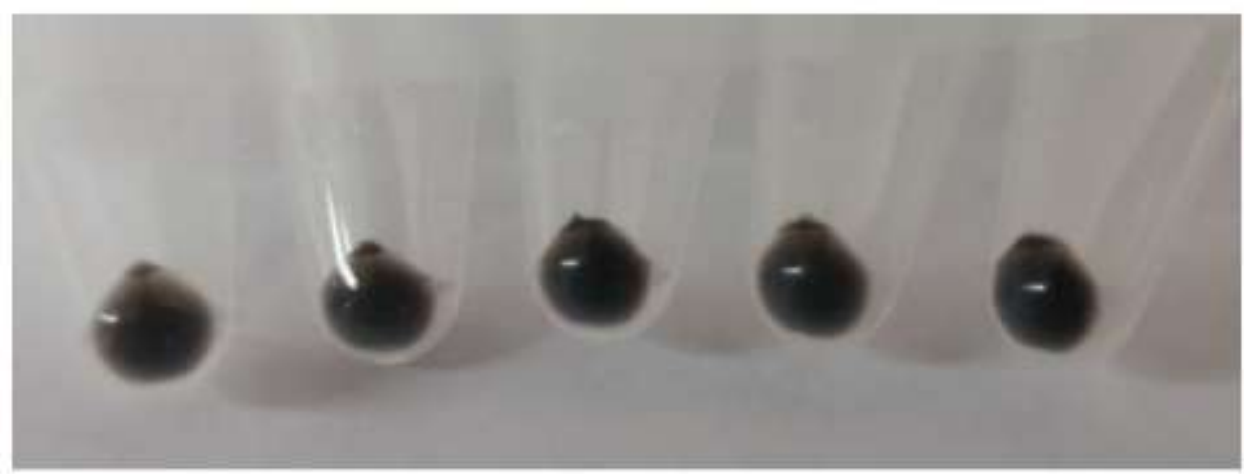

\section{Control Ethanol $5 \mu \mathrm{g} / \mathrm{mL} \quad 10 \mu \mathrm{g} / \mathrm{mL} \quad 20 \mu \mathrm{g} / \mathrm{mL}$}

\section{L. bicolor extract}

Fig. 4. L. bicolor extract increases melanogenesis in B16 melanoma cells. The dark-black color of the B16 melanoma cell pellets demonstrate that control (untreated), ethanol and the L. bicolor extract. Control: untreated; Ethanol: $60 \%$ ethanol

In confirmation of the results of Fig. 4, the increase of melanin biosynthesis and secretion shows a distinct black color of the cell pellet. Hamid et al. (2012) reported that the dark-black color of the B16F1 melanoma cell pellets demonstrated that $\alpha-\mathrm{MSH}$, forskolin, and mangosteen leaf extract stimulated melanogenesis activity. Nair et al. (2001) evaluated repigmentation, as determined by cell pellet color and melanin assays. The colors of cell pellets are evaluated visually for melanin content assay (Usuki et al. 2003). These observations suggest that the L. bicolor extract increased the melanogenic activity of B16 melanoma cells.

\section{Effect of L. bicolor Extract on Tyrosinase Activity}

Effect of L. bicolor extract on mushroom tyrosinase activity

To determine whether L. bicolor ethanol extract had a direct effect on the major enzyme in the melanogenesis, an in vitro cell-free mushroom tyrosinase assay was conducted. The effects of $L$. bicolor ethanol extract on mushroom tyrosinase activity are shown in Fig. 5. The effects of the extract on the oxidation of L-DOPA by mushroom tyrosinase occurred in a dose-dependent manner. At $10 \mu \mathrm{g} / \mathrm{mL}$ and $20 \mu \mathrm{g} / \mathrm{mL}$, L. bicolor ethanol extract exerted activity on the oxidation of L-DOPA by mushroom tyrosinase; the $10 \mu \mathrm{g} / \mathrm{mL}$ L. bicolor ethanol extract showed lower activity than the $20 \mu \mathrm{g} / \mathrm{mL}$ L. bicolor ethanol extract. However, there was no significant difference between the two concentrations. Tyrosinase catalyzes 3,4-dihydroxyphenylalanine (DOPA) quinone formation from DOPA, and melanin formation from DOPA quinone via autoxidation and enzymatic reaction (Jimenez et al. 1993). Therefore, melanin production is related to tyrosinase expression; the results presented here were similar. More specifically, both the melanin content and tyrosinase activity were increased by $10 \mu \mathrm{g} / \mathrm{mL}$ and $20 \mu \mathrm{g} / \mathrm{mL} L$. bicolor extract (Figs. 3 and 5). It is anticipated that continued research will increase knowledge concerning the activity of tyrosinase in L. bicolor ethanol extract, and continue to shed light on therapeutic strategies that can be used to reduce or eliminate vitiligo. Most studies have been performed on the effect of the mushroom tyrosinase from various plant extracts (Kim et al. 2003; Hsu et al. 2007). Thus, L. bicolor extract may be noted as an effective material with mushroom tyrosinase activity. 


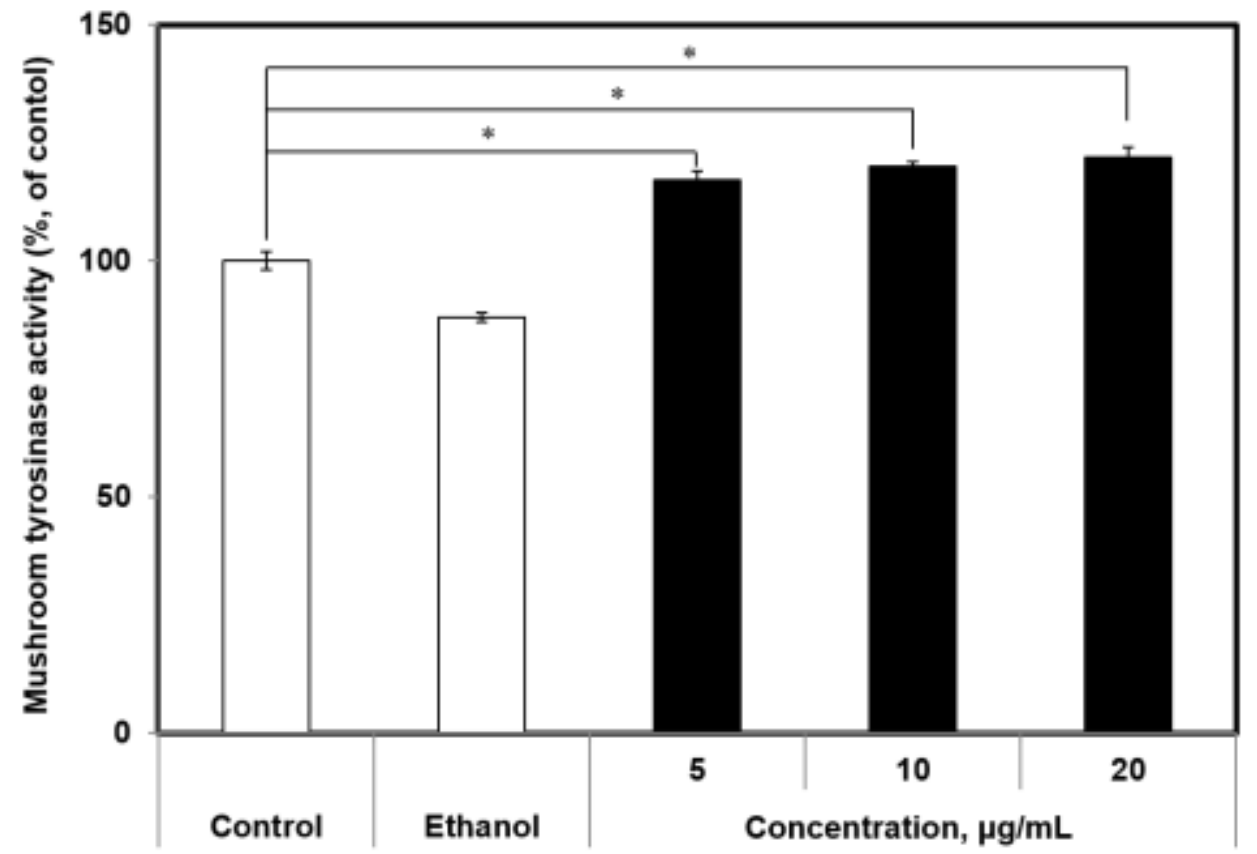

Fig. 5. Effects of $L$. bicolor ethanol extract on mushroom tyrosinase activity. Purified tyrosinase was mixed with L. bicolor ethanol extract and incubated with L-DOPA. Control: untreated; Ethanol: 60 $\%$ ethanol; Concentration: $L$. bicolor ethanol extract. * $p<0.05$ compared to the untreated control.

\section{Effect of L. bicolor extract on tyrosinase activity in B16 melanoma cells}

Tyrosinase catalyzes three steps in the biosynthesis process of melanin; hence, the measurement of tyrosinase activity is very important. The intracellular tyrosinase activity was measured after the culture of B16 melanoma cells with L. bicolor ethanol extract. Different concentrations of L. bicolor extract, not mushroom tyrosinase, were used to treat cell lysats extracted from B 16 melanoma cells. Equal masses of cell lysate were prepared with respect to the protein concentration. At $5 \mu \mathrm{g} / \mathrm{mL} \mathrm{L}$. bicolor extract, a weak effect on the direct activation of intracellular tyrosinase was observed, but tyrosinase-inducing activity was increased significantly by $10 \mu \mathrm{g} / \mathrm{mL}$ and $20 \mu \mathrm{g} / \mathrm{mL}$ L. bicolor extract (Fig 6). Chen et al. (2012) showed that tyrosinase was regarded as the rate-limiting enzyme of melanogenesis, which modulates this process through the catalysis of the hydroxylation of tyrosine into DOPA and the further oxidation of DOPA into dopaquinone. Matsuda et al. (2005) confirmed the potential stimulation of melanogenesis from tyrosinase activity by using cultured B16 melanoma cells. The activity of tyrosinase in melanocytes may be expressed in tyrosinase cells due to direct activity or an increase in the total amount of protein in the cell (Oh et al. 2011). In the previous results, L. bicolor extract exerted a significant influence on tyrosinase activity. This result shows that the L. bicolor extract can be used directly as a tyrosinase activator. In a previous study (Jung et al. 2001), the cellular tyrosinase activity was also increased dose-dependently by glycyrrhizin, reaching $220 \%$ of the value in control cells at a treatment concentration of $1 \mathrm{mM}$. Adzuki bean extract is known to have a weak effect on the direct activation of tyrosinase in cells (Itoh and Furuichi 2005). Tuerxuntayi et al. (2014) reported that, compared with untreated conditions, treatment with Kaliziri extract at 5 to $40 \mu \mathrm{g} / \mathrm{mL}$ resulted in a dose-dependent increase in tyrosinase activity in B16 cells (to a maximum of $138 \%$ tyrosinase activity). Treatment with forskolin significantly increased the intracellular tyrosinase activity by more than 
three-fold, whereas treatment with $32 \mu \mathrm{g} / \mathrm{mL}$ extract demonstrated a four-fold increase in intracellular tyrosinase activity (Hamid et al. 2012). These results suggested that L. bicolor extract is a stimulant of tyrosinase, similar to other natural extracts; moreover, melanin synthesis increases as tyrosinase activity increased.

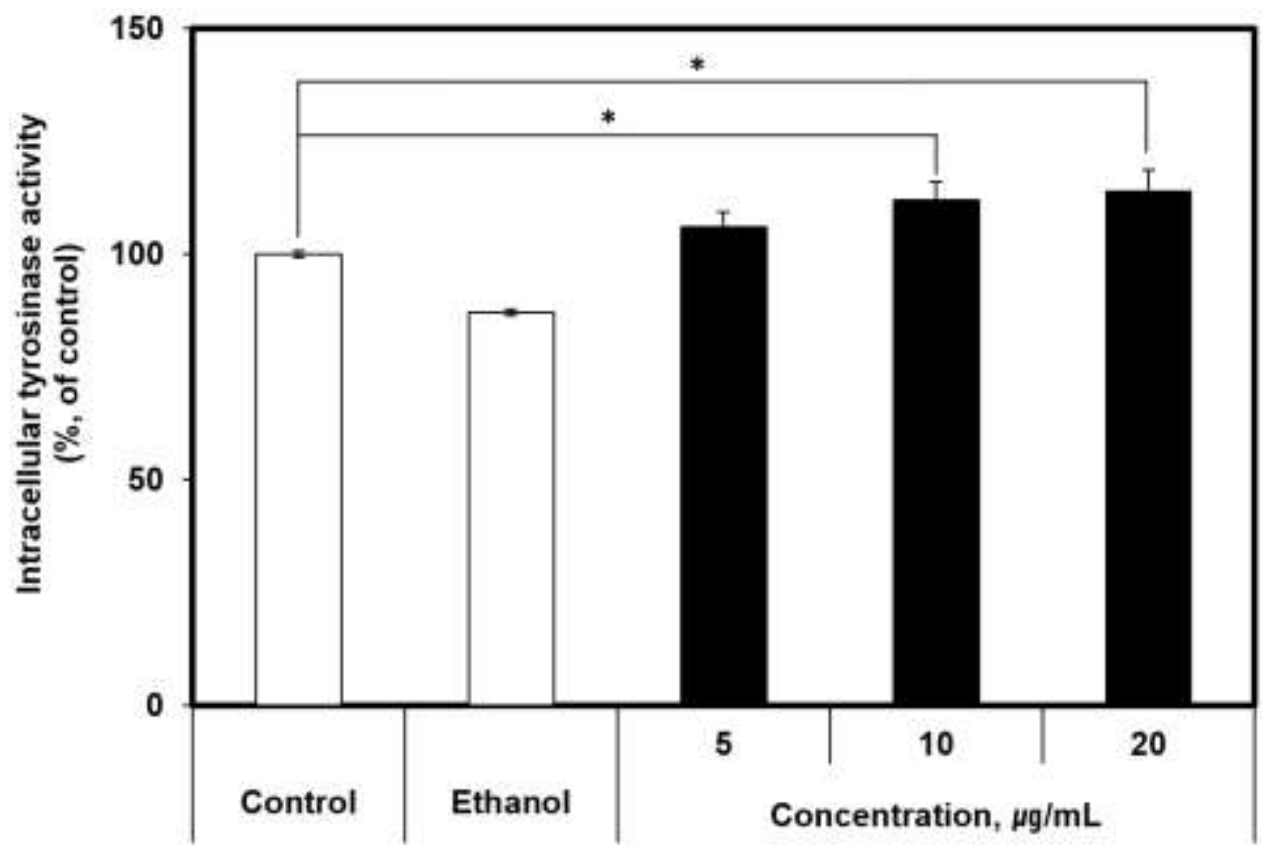

Fig. 6. Effect of $L$. bicolor ethanol extract on intracellular tyrosinase activity in B16 melanoma cells (Control: untreated; Ethanol: $60 \%$ ethanol treated).

${ }^{*} \mathrm{p}<0.05$ compared to the untreated control.

\section{Effect of L. bicolor Extract on Melanin Content in C57BL/6J Ler-vit/vit Mice Hair}

Before the experiment, the health status of the mice were normal. The experiment was conducted using a total of 15 mice, which were used for all experiments. Melanin contents in the hair samples taken from the back of C57BL/6J Ler-vit/vit mice were significantly higher in those treated with L. bicolor ethanol extract than in the control group ( $\mathrm{p}<0.01$ ) (Fig. 7). Therefore, the L. bicolor extract has the potential to assist repigmentation in vitiligo because it increased melanin content by approximately $40 \%$ compared with the control. In vertebrates and higher mammals, melanin plays an important role in thermoregulation, gastrointestinal tract, sexual attraction, and photoprotection. These melanin pigments can be distinguished chemically by the red-yellow pheomelanin and the brown-black eumelanin. Both types of melanin are found in human hair, the epidermis, and cultured melanocytes. The main synthesis process for these two pigments is similar and is controlled by tyrosinase. However, the production of eumelanin is important for repigmentation in the treatment of vitiligo. 


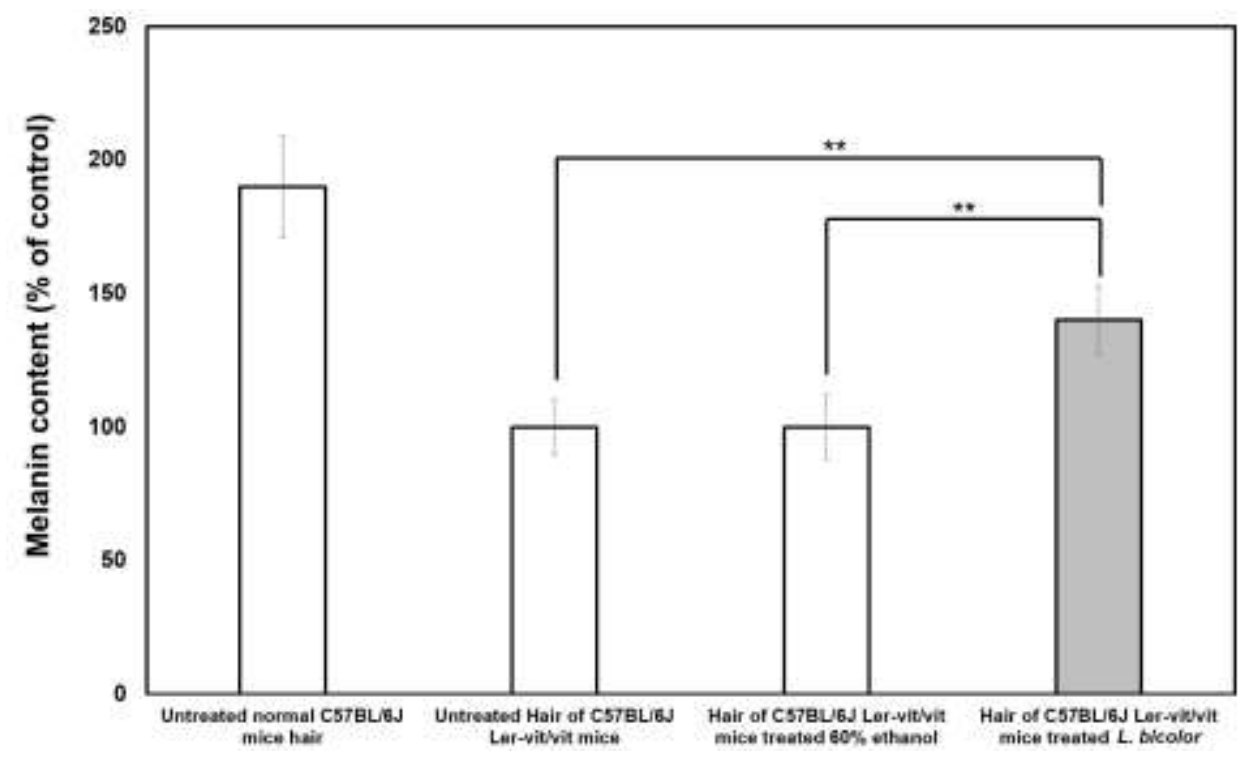

Fig. 7. Effect of $L$. bicolor ethanol extract on melanin content of hair in C57BL/6J Ler-vit/vit mice. The mice hair was lysed with $1 \mathrm{~N} \mathrm{NaOH}$ and the absorbance of the solution at $500 \mathrm{~nm}$ was measured. C57BL/6J Ler-vit/vit mice: vitiligo mice hair; C57BL/6J: normal mice hair.

${ }^{* *} p<0.01$ compared to the control

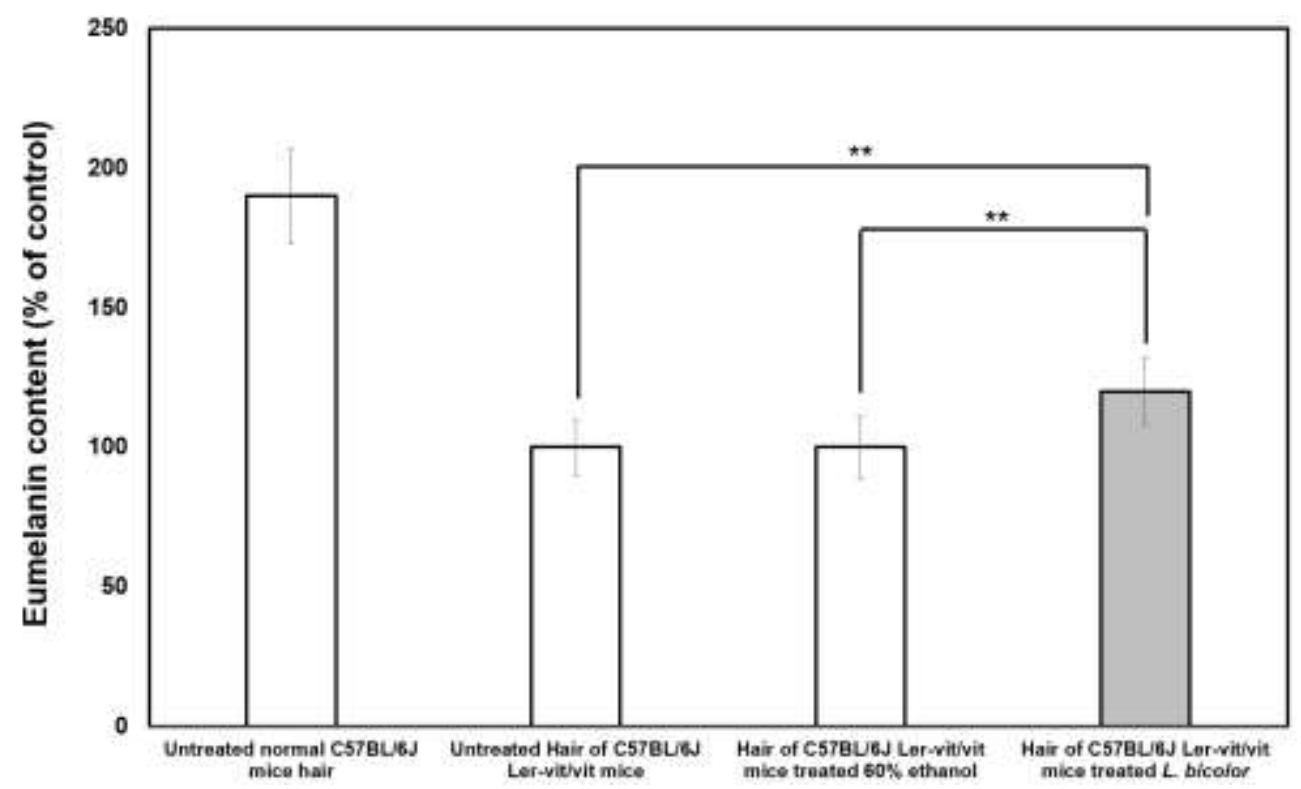

Fig. 8. Effect of $L$. bicolor ethanol extract on eumelanin content of hair in C57BL/6J Ler-vit/vit mice. The mice hair was lysed with $1 \mathrm{~N} \mathrm{NaOH}$ and the absorbance of the solution at $650 \mathrm{~nm}$ was measured. C57BL/6J Ler-vit/vit mice: vitiligo mice hair; C57BL/6J: normal mice hair.

${ }^{* *} p<0.01$ compared to the control

The effect of $L$. bicolor extract on the eumelanin content of mouse hair is shown in Fig. 8. Treatment with $L$. bicolor extract resulted in significantly higher eumelanin content than the control $(60 \%$ ethanol) in the hair of C57BL/6J Ler-vit/vit mice hair $(\mathrm{p}<0.01)$. Although treatment with $L$. bicolor extract resulted in a lower eumelanin content than the hair of the normal C57BL/6J mice, the L. bicolor extract was effective in increasing the eumelanin content in mice hair. Yonemoto et al. (1983) reported a decrease in eumelanin 
content in the lesions of vitiligo induced by 4-tertiary butyl catechol. Vitiligo occurs when there is a decrease in melanocytes and, in particular, when eumelanin is not formed (Prasad et al. 2003). Vitiligo affects the skin, head, and other parts of the body (Mihăilă et al. 2019). Thus, the results suggest that L. bicolor extracts can be used for repigmentation in the treatment of vitiligo.

\section{Effect of L. bicolor extract on Melanin Cells in the Histology of C57BL/6J Ler-vit/vit Mice}

Melanin cells around hair follicles observed under an optical microscope correspond, by their localization, to the DOPA-positive cells. Their morphological features are characteristic of melanocytes. Figure 9 shows representative sections of C57BL/6J Ler$\mathrm{vit} / \mathrm{vit}$ mice skin stained for melanin. Microscopic examination revealed pigmented areas, with more repigmentation after treatment with L. bicolor ethanol extract than the $60 \%$ ethanol used as a control. L. bicolor extract promoted a melanocytic response and the concentration required for the promotion of pigmentation was $0.2 \mathrm{~mL} / \mathrm{cm}^{2}$. These observations confirmed that L. bicolor extract restored vitiligo pigmentation. Interestingly, L. bicolor extracts cause a lot of pigmentation around mice hair follicles. The presence of melanocytes in the surrounding the root of mice hair follicles has already been documented (Ito and Wakamatsu 2003). This was consistent with the scientific literature affirming that repigmentation occurs mainly in the areas of skin where there were still pigmented hairs, as this suggests the presence of melanin reservoirs (Menon et al. 2016). Thus, the repigmentation of the epidermis following dermabrasion originates from the melanotic portion of the hair follicle. These results confirmed that $L$. bicolor extract was an effective stimulator of the melanin stored around the hair follicles.

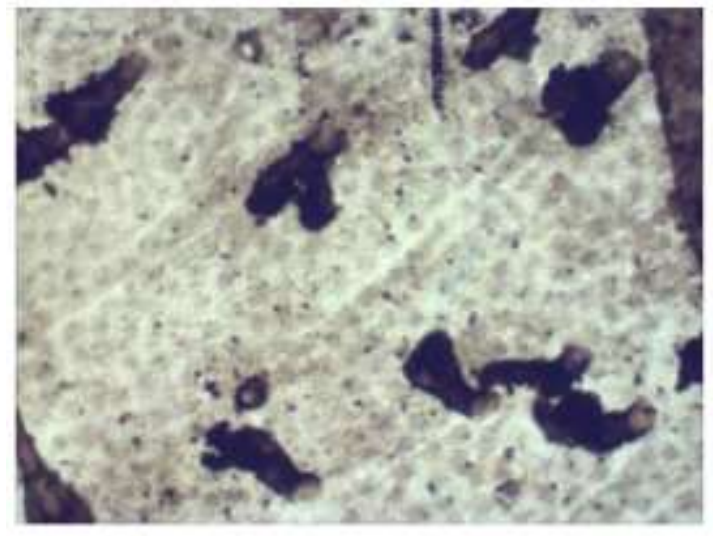

Control

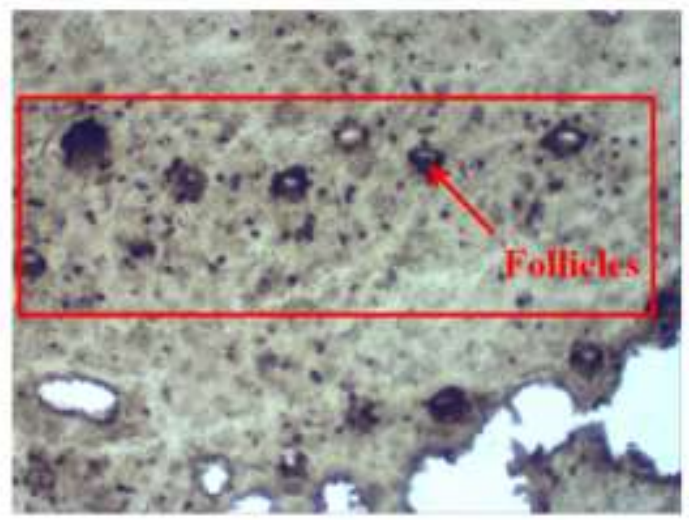

L. bicolor

Fig. 9. Histologic examination of C57BL/6J Ler-414 vit/vit mice skin sections stained for melanin ( $\times$ 100). Control: C57BL/6J Ler-vit/vit mice treated 60\% ethanol; L. bicolor: C57BL/6J Ler-vit/vit mice treated L. bicolor ethanol extract applied $0.2 \mathrm{~mL} / \mathrm{cm}^{2}$

\section{High-performance Liquid Chromatography (HPLC) Detection of Quercetin in L. bicolor Extract}

L. bicolor extract was reported to contain flavonoid compounds, such as quercetin, kaempferol, trifolin, isoquercitrin, and homoorietin (Qi et al. 2011). A quercetin was previously isolated as the principal regulator of tyrosinase from the dried flower of Heterotheca inuloides Cass (Compositae), known as "arnica" in Mexico (Rodríguez- 
Chávez et al. 2015). In addition, quercetin was previously reported to control the oxidation of 1-3,4-dihydroxyphenylalanine (L-DOPA, 2) catalyzed by mushroom tyrosinase (Kubo et al. 1994). Studies have investigated the effects of quercetin on tyrosinase activity and melanogenesis (Takekoshi et al. 2013). Nagata et al. (2004) demonstrated that the treatment of cultured melanoma cells with quercetin enhanced melanogenesis and also increased tyrosinase activity. HPLC analysis was performed to determine if quercetin was contained in the L. bicolor extracts that were produced by the authors. The application of HPLC to the study of quercetin in L. bicolor extract is shown in Fig. 10. The L. bicolor extract had the same retention time as the quercetin standard, which meant that quercetin was present in the L. bicolor extract. This was similar to previous studies that reported quercetin was contained in L. bicolor extracts (Glyzin et al. 1970). Therefore, it appears that quercetin plays a role in the melanogenic activity of $L$. bicolor extracts. Moreover, $L$. bicolor extract is a potential source of quercetin for melanogenesis.

A

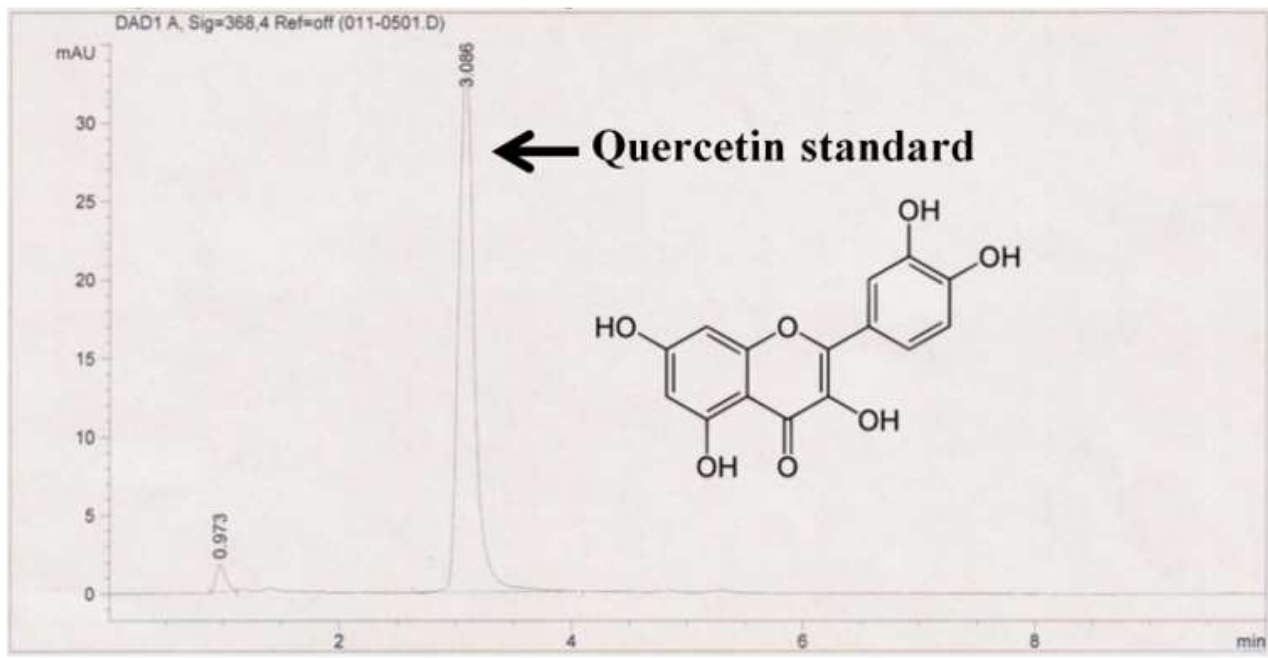

B

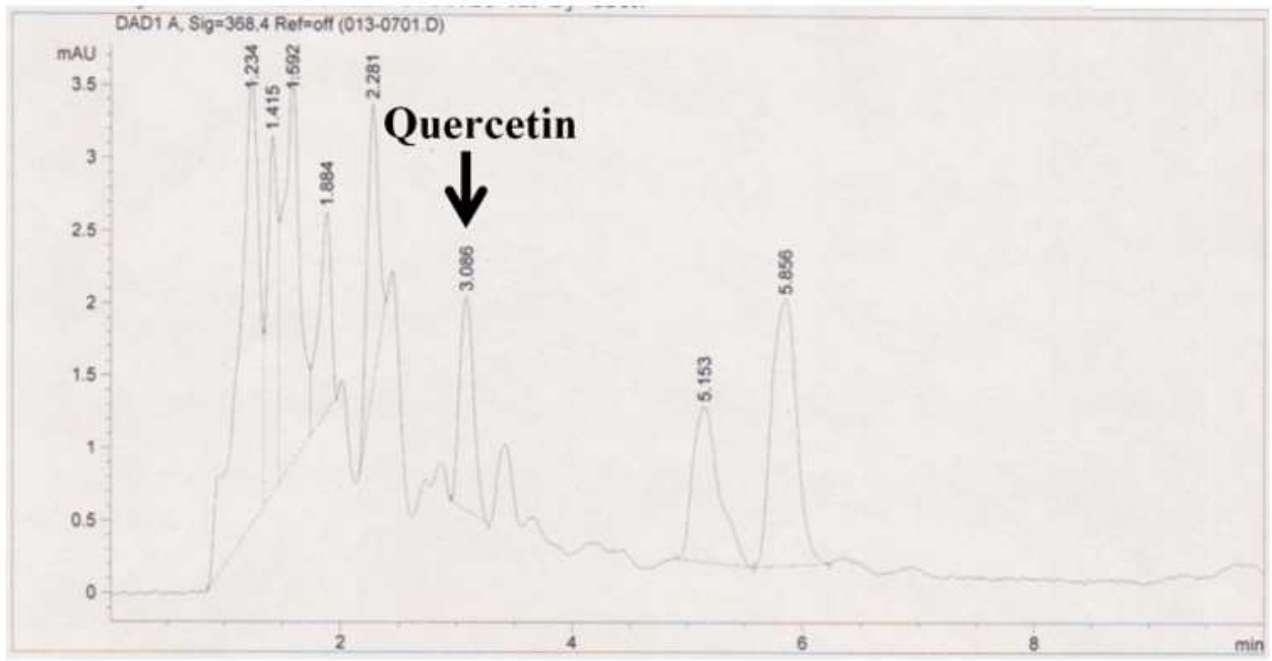

Fig. 10. The content of quercetin of the standard and L. bicolor extract by HPLC were shown. A: Quercetin standard (Retention time: $3.086 \mathrm{~min}$ ), B: L. bicolor extract. 


\section{CONCLUSIONS}

1. The effects of extract from L. bicolor on melanogenesis and tyrosinase activity were evaluated in B16 melanoma cells and C57BL/6J Ler-vit/vit mice. The results demonstrated the L. bicolor extract enhanced melanogenesis and increased tyrosinase activity in cultured melanoma cells and C57BL/6J Ler-vit/vit mice.

2. Treatment with L. bicolor extract led to a higher content of melanin and eumelanin in C57BL/6J Ler-vit/vit mice hair than in control (60\% ethanol) mice, which demonstrated the therapeutic effect of hair-graying associated with vitiligo.

3. There was a notable increase in melanocytes in the skin of C57BL/6J Ler-vit/vit mice treated with $L$. bicolor extract compared with the control.

4. This study provides experimental evidence that $L$. bicolor could be used as an effective treatment for the treatment of vitiligo and other skin diseases.

\section{ACKNOWLEDGMENTS}

This research was supported by 2019 Basic Science Research Program through the National Research Foundation of Korea (NRF) funded by the Ministry of Education (2018R1D1A1A02045243)"

\section{REFERENCES CITED}

Boissy, R. E., Moellmann, G. E., and Lerner, A. B. (1987). "Morphology of melanocytes in hair bulbs and eyes of vitiligo mice," The American Journal of Pathology 127(2), 380-388

Chen, L. H., Hu, Y. H., Song, W., Song, K. K., Liu, X., Jia, Y. L., Zhuang, J. X., and Chen, Q. X. (2012). "Synthesis and antityrosinase mechanism of benzaldehyde thiosemicarbazones: Novel tyrosinase inhibitors," Journal of Agricultural and Food Chemistry 60(6), 1542-1547. DOI: 10.1021/jf204420x

Glyzin, V. I., Ban'kovskii, A. I., Zhurba, O. V., and Sheichenko, V. I. (1970). "Flavonoids of Lespedeza bicolor," Chemistry of Natural Compounds 6(4), 487-488.

Green, S. J., and Wilson, J. F. (1996). "The effect of hair color on the incorporation of methadone into hair in the rat," Journal of analytical toxicology 20(2), 121-123. DOI: 10.1093/jat/20.2.121

Hamid, M. A., Sarmidi, M. R., and Park, C. S. (2012). "Mangosteen leaf extract increases melanogenesis in $\mathrm{B} 16 \mathrm{~F} 1$ melanoma cells by stimulating tyrosinase activity in vitro and by up-regulating tyrosinase gene expression," International Journal of Molecular Medicine 29(2), 209-217. DOI: 10.3892/ijmm.2011.840

Hsu, C. K., Chang, C. T., Lu, H. Y., and Chung, Y. C. (2007). "Inhibitory effects of the water extracts of Lavendula sp. on mushroom tyrosinase activity," Food Chemistry 105(3), 1099-1105. DOI: 10.1016/j.foodchem.2007.02.008

Huberman, E., and Callaham, M. F. (1979). "Induction of terminal differentiation in human promyelocytic leukemia cells by tumor-promoting agents," Proceedings of the National Academy of Sciences 76(3), 1293-1297. DOI: 10.1073/pnas.76.3.1293

Ha et al. (2020). "Lespedeza bicolor extract properties," BioResources 15(3), 6244-6261. 6258 
Ito, S., and Wakamatsu, K. (2003). "Quantitative analysis of eumelanin and pheomelanin in humans, mice, and other animals: A comparative review," Pigment Cell Research 16(5), 523-531. DOI: 10.1034/j.1600-0749.2003.00072.x

Itoh, T., and Furuichi, Y. (2005). "Hot-water extracts from adzuki beans (Vigna angularis) stimulate not only melanogenesis in cultured mouse B16 melanoma cells but also pigmentation of hair color in $\mathrm{C} 3 \mathrm{H}$ mice," Bioscience, Biotechnology, and Biochemistry 69(5), 873-882. DOI: 10.1271/bbb.69.873

Jimenez-Cervantes, C., Garcia-Borron, J. C., Valverde, P., Solano, F., and Lozano, J. A. (1993). "Tyrosinase isoenzymes in mammalian melanocytes. 1. Biochemical characterization of two melanosomal tyrosinases from B16 mouse melanoma," European Journal of Biochemistry 271(2), 549-556. DOI: 10.1111/j.14321033.1993.tb18276.x

Jung, G. D., Yang, J. Y., Song, E. S., and Park, J. W. (2001). "Stimulation of melanogenesis by glycyrrhizin in B16 melanoma cells," Experimental \& Molecular Medicine 33(3), 131. DOI: 10.1038/emm.2001.23

Kang, S. H., Jeon, Y. D., Cha, J. Y., Hwang, S. W., Lee, H. Y., Park, M., Lee, B. R., Shin, M. K., Kim, S. J., Shin, S. M., Kim, D. K., Jin, J. S., and Lee, Y. M. (2018). "Antioxidant and skin-whitening effects of aerial part of Euphorbia supina Raf. Extract," BMC Complementary and Alternative Medicine 18(1), 256. DOI: 10.1186/s12906-018-2323-5

Kim, S. J., Son, K. H., Chang, H. W., Kang, S. S., and Kim, H. P. (2003). “Tyrosinase inhibitory prenylated flavonoids from Sophora flavescens," Biological and Pharmaceutical Bulletin 26(9), 1348-1350. DOI: 10.1248/bpb.26.1348

Kubo, I., Kinst-Hori, I., and Yokokawa, Y. (1994). "Tyrosinase inhibitors from Anacardium occidentale fruits," Journal of Natural Products 57(4), 545-551

Kubo, I., Nihei, K., and Tsujimoto, K. (2004). "Methyl p-coumarate, a melanin formation inhibitor in B16 mouse melanoma cells," Bioorganic \& Medicinal Chemistry 12, 5349-5354. DOI: 10.1016/j.bmc.2004.07.052

Laidlaw, G. F., and Blackberg, S. N. (1932). "Melanoma studies: II. A simple technique for the dopa reaction," The American Journal of Pathology 8(5), 491

Lan, C. C., Chen, G. S., Chiou, M. H., Wu, C. S., Chang, C. H., and Yu, H. S. (2005). "FK506 promotes melanocyte and melanoblast growth and creates a favourable milieu for cell migration via keratinocytes: Possible mechanisms of how tacrolimus ointment induces repigmentation in patients with vitiligo," British Journal of Dermatology 153(3), 498-505. DOI: 10.1111/j.1365-2133.2005.06739.x

Lin, Z. X., Hoult, J. R. S., and Raman, A. (1999). "Sulphorhodamine, B assay for measuring proliferation of a pigmented melanocyte cell line and its application to the evaluation of crude drugs used in the treatment of vitiligo," Journal of Ethnopharmacology 66(2), 141-150. DOI: 10.1016/S0378-8741(98)00199-8

Madhogaria, S., and Ahmed, I. (2010). "Leucoderma after use of a skin-lightening cream containing kojic dipalmitate, liquorice root extract and Mitracarpus scaber extract," Clinical and Experimental Dermatology: Experimental dermatology 35(4), e103e105. DOI: 10.1111/j.1365-2230.2009.03690.x

Masamoto, Y., Ando, H., Murata, Y., Shimoishi, Y., Tada, M., and Takahata, K. (2003). "Mushroom tyrosinase inhibitory activity of esculetin isolated from seeds of Euphorbia lathyris L," Bioscience, Biotechnology, and Biochemistry 67(3), 631-634. DOI: $10.1271 / \mathrm{bbb} .67 .631$

Matsuda, H., Hirata, N., Kawaguchi, Y., Yamazaki, M., Naruto, S., Shibano, M., 
Taniguchi, M., Baba, K., and Kubo, M. (2005). "Melanogenesis stimulation in murine B16 melanoma cells by umberiferae plant extracts and their coumarin constituents," Biological and Pharm. Bulletin 28(7), 1229-1233. DOI: 10.1248/bpb.28.1229

Matsuyama, K., Villareal, M. O., El-Omri, A., Han, J., Elyes-Kchouk, M. and Isoda, H. (2009). "Effect of Tunisian Capparis spinosa L. extract on melanogenesis in B16 murine melanoma cells," Journal of Natural Medicines 63(4), 468-472. DOI: 10.1007/s11418-009-0355-3

Medrano, E. E., and Nordlund, J. J. (1990). "Successful culture of adult human melanocytes obtained from normal and vitiligo donors," The Journal of Investigative Dermatology 95(4), 441-445

Menon, J. M., Vijil, V. V., Aswathi, P. S., Nimitha, K. N., Athira, L., Vijayalakshmi, S. V., Sruthi, P. S., Sughi, S., and Kurian, N. K. (2016). "Evaluation of antimelanogenic activity of Pterocarpus santalinus L. using bacterial system," Biotechnological Research 2(2), 58-60.

Mihăilă, B., Dinică, R. M., Tatu, A. L., and Buzia, O. D. (2019). "New insights in vitiligo treatments using bioactive compounds from Piper nigrum," Experimental and Therapeutic Medicine 17(2), 1039-1044. DOI: 10.3892/etm.2018.6977

Mosmann, T. (1983). "Rapid colorimetric assay for cellular growth and survival: Application to proliferation and cytotoxicity assays," Journal of Immunological Methods 65(1-2), 55-63

Nagata, H., Takekoshi, S., Takeyama, R., Homma, T., and Yoshiyuki-Osamura, R. (2004). "Quercetin enhances melanogenesis by increasing the activity and synthesis of tyrosinase in human melanoma cells and in normal human melanocytes," Pigment Cell Research 17(1), 66-73. DOI: 10.1046/j.1600-0749.2003.00113.x

Nair, S. S., Chaubal, V. A., Shioda, T., Coser, K. R., and Mojamdar, M. (2001). "Overexpression of MSG1 transcriptional co-activator increases melanin in B16 melanoma cells: a possible role for MSG1 in melanogenesis," Pigment Cell Research 14(3), 206-209. DOI: 10.1034/j.1600-0749.2001.140311.x

Niu, C., Yin, L., Nie, L. F., Dou, J., Zhao, J. Y., Li, G., and Aisa, H. A. (2016). "Synthesis and bioactivity of novel isoxazole chalcone derivatives on tyrosinase and melanin synthesis in murine B16 cells for the treatment of vitiligo," Bioorganic \& Medicinal Chemistry 24(21), 5440-5448. DOI: 10.1016/j.bmc.2016.08.066

Oh, M. J., Hamid, M. A., Ngadiran, S., Seo, Y. K., Sarmidi, M. R., and Park, C. S. (2011). "Ficus deltoidea (Mas cotek) extract exerted anti-melanogenic activity by preventing tyrosinase activity in vitro and by suppressing tyrosinase gene expression in B16F1 melanoma cells," Archives of Dermatological Research 303(3), 161-170. DOI: $10.1007 / \mathrm{s} 00403-010-1089-5$

Pomerantz, S. H. (1964). "Tyrosine hydroxylation catalyzed by mammalian tyrosinase: An improved method of assay," Biochemical and Biophysical Research Communications 16(2), 188-194. DOI: 10.1016/0006-291X(64)90359-6

Prasad, M. L., Busam, K. J., Patel, S. G., Hoshaw-Woodard, S., Shah, J. P., and Huvos, A. G. (2003). "Clinicopathologic differences in malignant melanoma arising in oral squamous and sinonasal respiratory mucosa of the upper aerodigestive tract,"

Archives of Pathology \& Laboratory Medicine 127(8), 997-1002. DOI: 10.1043/1543-2165

Qi, X., Tang, Y., Jian, H. L., Li, X., and Jiang, J. X. (2011). "Production of lactic acid by simultaneous saccharification and fermentation using steam pretreated lespedeza stalks as inexpensive raw materials," in: Advanced Materials Research, Trans. Tech. 
Publications 152, pp. 1404-1411.

Rafiq, M., Sancheti, S. S., Kim, H. R., You, Y. H., and Seo, S. Y. (2013).

"Antihyperglycemic and antioxidant activities of Rhododendron schlippenbachii

maxim. Bark and its various fractions," Journal of Medicinal Plants Research 7(12), 713-719. DOI: 10.5897/JMPR12.071

RodrÍguez-chÁvez, J. L., Rufino-Gonzalez, Y., Ponce-Macotela, M., and Delgado, G. (2015). "In vitro activity of 'Mexican Arnica' Heterotheca inuloides Cass natural products and some derivatives against Giardia intestinalis," Parasitology 142(4), 576-584. DOI: 10.1017/S0031182014001619

Samiullah, Bano, A., Girmay, S., and Tan, G. (2012). "Total phenolic content, antioxidant, antimicobial and anticancer activities of Lespedeza bicolor Turcz (Papilionaceae)," in: International Conference on Applied Life Sciences, Konya, Turkey, p. 259-264. DOI: 10.5772/intechopen.84088

Slominski, A., and Paus, R. (1993). "Melanogenesis is coupled to murine anagen: Toward new concepts for the role of melanocytes and the regulation of melanogenesis in hair growth," Journal of Investigative Dermatology 101(1), S90-S97. DOI: 10.1016/0022-202X(93)90507-E

Song, Y. H., Connor, E., Li, Y., Zorovich, B., Balducci, P., and Maclaren, N. (1994). "The role of tyrosinase in autoimmune vitiligo," The Lancet 344(8929), 1049-1052. DOI: 10.1016/S0140-6736(94)91709-4

Szczurko, O., Shear, N., Taddio, A., and Boon, H. (2011). "Ginkgo biloba for the treatment of vitilgo vulgaris: An open label pilot clinical trial," BMC Complementary and Alternative Medicine 11(1), 21. DOI: 10.1186/1472-6882-11-21

Tahir, M. A., Pramod, K., Ansari, S. H., and Ali, J. (2010). "Current remedies for vitiligo," Autoimmunity Reviews 9(7), 516-520. DOI: 10.1016/j.autrev.2010.02.013

Takekoshi, S., Matsuzaki, K., and Kitatani, K. (2013). "Quercetin stimulates melanogenesis in hair follicle melanocyte of the mouse," The Tokai Journal of Experimental and Clinical Medicine 38, 129-134

Tuerxuntayi, A., Liu, Y. Q., Tulake, A., Kabas, M., Eblimit, A., and Aisa, H. A. (2014). "Kaliziri extract upregulates tyrosinase, TRP-1, TRP-2 and MITF expression in murine B16 melanoma cells," BMC Complementary and Alternative Medicine 14(1), 166. DOI: $10.1186 / 1472-6882 / 14 / 166$

Usuki, A., Ohashi, A., Sato, H., Ochiai, Y., Ichihashi, M., and Funasaka, Y. (2003). "The inhibitory effect of glycolic acid and lactic acid on melanin synthesis in melanoma cells," Experimental Dermatology 12, 43-50. DOI: 10.1034/j.1600-0625.12.s2.7.x

Whitton, M. E., Pinart, M., Batchelor, J. M., Leonardi-Bee, J., Gonzalez, U., Jiyad, Z., Eleftheriadou, V., and Ezzedine, K. (2016). "Evidence-based management of vitiligo: Summary of a Cochrane systematic review," British Journal of Dermatology 174(5), 962-969. DOI: 10.1111/bjd.14356

Yonemoto, K., Gellin, G. A., Epstein, W. L., and Fukuyama, K. (1983). "Reduction in eumelanin by the activation of glutathione reductase and $\gamma$-glutamyl transpeptidase after exposure to a depigmenting chemical," Biochemical Pharmacology 32(8), 13791382. DOI: 10.1016/0006-2952(83)90450-1

Article submitted: March 31, 2020; Peer review completed: June 4, 2020; Revised version received and accepted: June 23, 2020; Published: July 1, 2020.

DOI: 10.15376/biores. 15.3.6244-6261 